\title{
IMPLEMENTASI NILAI-NILAI MULTIKULTURAL DI SEKOLAH DASAR
}

\section{Kurotul Aeni dan Tri Astuti}

Pendidikan Guru Sekolah Dasar Fakultas Ilmu Pendidikan Universitas Negeri Semarang Email: threeas tuti@yahoo.com

\begin{tabular}{l}
\hline Info Artikel \\
\hline Sejarah Artikel: \\
Diserahkan 27 Januari 2020 \\
Direvisi 5 Februari 2020 \\
Direvisi 24 April 2020 \\
Direvisi 22 Mei 2020 \\
Disetujui 22 Mei 2020 \\
\hline
\end{tabular}

Keywords:

multicultural values,

character,

elementary

\begin{abstract}
The research aims to describe and analyze the implementation of multicultural values in SD Global Inbyra School (GIS) and SD Pelita Harapan Bangsa (PHB).

The research method used is the naturalistic inquiry case study approach. Retrieval of data using observations, interviews, and documentation. The validity of the data is done by confirming the results of observations, interviews, documentation. Data credibility testing is done by extending observations, increasing persistence, triangulation of data, member checks, and references. Data analysis uses the interactive model of Miles \& Huberman. The results showed that the implementation of multicultural values in GIS and PHB as follows 1) was carried out in an integrated manner through intracuricular and extracurricular activities; 2) The role is very dominant shown by the principal, teachers, and students have the same understanding and positive influence in the development of multicultural values as an effort to build the character of students. The differences are (1) in SD GIS: (a) the application of English as the language of instruction makes students familiar with the term English in relation to the use of technology; confident in interacting with strangers / foreigners; (b) implementation of multicultural values through character building subjects; (c) the existence of a dual curriculum program, namely the integration and integration of national and international curricula (cambridge) that balances student potential, opportunities, ethnic background, religious beliefs and ideals to create individuals to socialize with different cultures.
\end{abstract}

\begin{abstract}
Abstrak
Penelitian bertujuan mendiskripsikan dan menganalisis implementasi nilai-nilai multikultural di SD Global Inbyra School (GIS) dan SD Pelita Harapan Bangsa (PHB).

Metode penelitian yang digunakan yaitu pendekatan naturalistik inquiry studi kasus. Pengambilan data menggunakan pengamatan, wawancara, dan dokumentasi. Keabsahan data dilakukan dengan konfirmasi hasil observasi, wawancara, dokumentasi. Uji kredibilitas data dilakukan dengan memperpanjang pengamatan, meningkatkan ketekunan, triangulasi data, member check, dan referensi. Analisis data menggunakan model interaktif Miles \& Huberman.

Hasil penelitian menunjukkan bahwa implementasi nilai-nilai multikultural di GIS dan PHB sebagai berikut 1) dilaksanakan secara terpadu melalui kegiatan intrakurikuler dan ekstrakurikuler; 2) Peran sangat dominan ditunjukkan oleh kepala sekolah, guru, dan siswa memiliki pemahaman yang sama dan berpengaruh positif dalam pengembangan nilai-nilai multikultural sebagai upaya membangun karakter peserta didik. Adapun perbedaannya yakni (1) di SD GIS: (a) penerapan bahasa Inggris sebagai bahasa pengantar membuat siswa tidak asing dengan istilah bahasa Inggris kaitannya dengan penggunaan teknologi; percaya diri dalam berinteraksi dengan orang asing/WNA; (b) implementasi nilai-nilai multikultural melalui mata pelajaran character building; (c) adanya program kurikulum ganda, yakni perpaduan dan pengintegrasian kurikulum nasional dan internasional (cambridge) yang menyeimbangkan potensi siswa, peluang, latar belakang etnis, keyakinan agama dan cita-cita guna menciptakan individu untuk bersosialisasi dengan budaya yang berbeda.
\end{abstract}

(C) 2020 Universitas Muria Kudus 


\section{PENDAHULUAN}

Kehidupan masyarakat Indonesia penuh dengan keragaman suku bangsa, bahasa, budaya, ras, kepercayaan, dan agama. Indonesia merupakan negara yang majenuk (Baldah, 2016). Berbagai persoalan di masyarakat terkait dengan isu perbedaan, seperti prasangka antar kelompok, kekerasan antar kelompok, tawuran antar pelajar, bullying anak sekolah pada sesama teman, menunjukkan betapa rentannya rasa kebersamaan dalam keragaman yang telah dibangun oleh para pendahulu bangsa. Persoalan tersebut memunculkan adanya diskriminasi di antara sesama. Persoalan ini tidak bisa dibiarkan terjadi, apalagi di kalangan anak sekolah Dasar. Pendidikan merupakan media yang tepat untuk mengenalkan multikultural (Wahyudin, 2017).

Desmita (2016) menjelaskan bahwa anak usia sekolah dasar 7 sampai 11 tahun berada pada tahap mythic- literal faith. Tahap perkembangan kognitifnya, berada pada perkembangan operasional konkret yakni memikirkan segala sesuatunya secara konkret; anak secara sistematis mulai mengambil makna tradisi masyarakatnya. Guru harus memahami karakteristik dan keberagaman peserta didik di sekolah, agar mampu mengelola kesetaraan guna meningkatkan kualitas pendidikan.

Berdasarkan pasal 4 (1) Undang-undang Nomor 20 tahun 2003, Permendikbud (2016) maka pengakuan atas perbedaan individual dan latar belakang budaya peserta didik perlu mendapatkan perhatian serius. Langkah strategisnya, yakni melalui pendidikan multikultural di Sekolah. Pendidikan multikultural merupakan suatu rangkaian kepercayaan dan penjelasan yang mengakui dan menilai pentingnya keragaman budaya dan etnis di dalam membentuk budaya hidup, pengalaman sosial, identitas pribadi, kesempatan pendidikan dari individu, kelompok maupun negara.

Pendidikan multikultural menurut Zamroni (2011) suatu bentuk reformasi pendidikan yang bertujuan untuk memberikan kesempatan yang setara kepada siswa tanpa memandang latar belakangnya, sehingga semua siswa dapat meningkatkan kemampuan yang setara optimal sesuai dengan ketertarikan, minat dan bakat yang dimiliki. Hanum (2009) menyatakan tujuan utama pendikan multikultural mengubah pendekatan pelajaran dan pembelajaran ke arah memberi peluang yang sama pada setiap anak, yakni: 1) tidak ada yang dikorbankan demi persatuan; 2) siswa ditanamkan pemikiran lateral, keanekaragaman; 3) keunikan itu dihargai. Hal ini berarti harus ada perubahan sikap, perilaku, dan nilai-nilai khususnya sivitas akademika sekolah. Penekanan pendidikan multikultural lebih difokuskan pada pendidikannya. Siswa seharusnya dilatih dan dibiasakan untuk memahami semua jenis pengetahuan, aktif mendiskusikan konstruksi pengetahuan dan interpretasi.

Penelitian mengenai pelaksanaan pendidikan multikultural telah dilakukan oleh beberapa peneliti antara lain oleh Lincoln (2011), Ismaya (2011), Sudrajat (2014) dan Najmina (2018). Riset Lincoln (2011) menunjukkan kesetaraan pendidikan selalu relatif dan pada proses menuju tingkat yang lebih tinggi baik secara kuantitas dan kualitas tergantung pada sejarah dan sosial tertentu; pemerataan pendidikan adalah cita-cita yang sulit dijangkau karena varietas masing-masing siswa, dalam hal latar belakang bahasa dan budaya, tingkat kognitif, kemampuan, dan gaya belajar, dan keterbatasan pengetahuan, keterampilan, dan profesionalisme guru, Lebih lanjut riset Ismaya (2011) menemukan bahwa belum ada praktek pendidikan multikultural di tiga sekolah yang diteliti. Praktek pendidikan multikultural tidak dilaksanakan karena tidak ada aturan atau kurikulum khusus yang mengharuskan praktek pendidikan multikultural. Akan tetapi yang terjadi adalah praktek multikulturalisme, dimana praktek multikulturalisme terjadi secara alami karena masing-masing pihak menyadari akan eksistensi orang lain dengan latar belakang suku, agama, etnis, budaya, gender, status sosial, dan tata nilai yang berbeda. Praktek multikulturalisme yang terjadi adalah pembelajaran multikultural yang dilakukan guru serta interaksi sosial dan pergaulan multikultural yang dilakukan siswa dalam lingkungan sekolah.

Sementara itu penelitian Sudrajat (2014) menunjukkan melalui sekolah, guru dapat menanamkan hakikat dan praktik pluralistis bagi peserta didik; guru perlu bertindak secara kreatif dalam menjembatani pluralitas menuju budaya yang plural dan damai; sebagai ujung tombak pendidikan multikultural, guru harus 
mempunyai pemahaman yang memadai tentang multikulturalisme dan pendidikan multikultural. Dalam kegiatan pembelajaran, guru mengembangkan iklim yang multicultureoriented yang mengedepankan keadilan sosial dan budaya bagi siswa, sehingga guru perlu melakukan transformasi diri menuju pribadi yang multikultur dan mempunyai desain pembelajaran yang berbasis multikultur yang tidak berorientasi pada kognitif semata. Lebih lanjut riset Najmina (2018) menunjukkan pendidikan multikulturalisme harus diterapkan dalam proses pembelajaran melalui proses pembiasaan, pembelajaran multikultural dilakukan dengan pembentukan pola pikir, sikap, tindakan, dan pembiasaan sehingga muncul kesadaran nasional keindonesiaan. Karakter keindonesiaan tersebut meliputi: kesadaran kebanggaan sebagai bangsa, kemandiriaan dan keberanian sebagai bangsa, kesadaran kehormatan sebagai bangsa, kesadaran melawan penjajahan, kesadaran berkorban demi bangsa, kesadaran nasionalisme bangsa lain, dan kesadaran kedaerahan menuju kebangsaan. Terwujudnya karakter keindonesiaan tersebut menjadi landasan kuat sebagai ciri khas manusia Indonesia yang kuat. Kekuatan keindonesiaan ini menjadi energi besar untuk menjadi Indonesia sebagai bangsa besar di tengah percaturan bangsa-bangsa di dunia. Bangsa besar hanya dapat diwujudkan melalui karakter manusia yang kuat. Karakter keindonesiaan melalui pendidikan multikulturalisme inilah salah satu harapan menuju Indonesia besar di masa depan.

Berdasarkan hal tersebut maka penelitian yang dilakukan bertujuan untuk mendiskripsikan dan menganalisis implementasi nilai-nilai multikultural di SD Global Inbyra School (GIS) dan SD Pelita Harapan Bangsa (PHB).

\section{METODE PENELITIAN}

Penelitian ini adalah penelitian kualitatif, dengan pendekatan naturalistik inquiry. Berdasarkan kondisi dan lingkungan objek penelitian yang berbeda, peneliti menggali data melalui observasi, wawancara mendalam dan dokumentasi.

Teknik pengumpulan data menggunakan pengamatan partisipan atau observasi, wawancara mendalam, dan dokumentasi. Teknik observasi partisipasi dilakukan dengan cara terlibat langsung secara aktif bersama objek yang diteliti. Wawancara terbuka dilaksanakan berdasarkan pedoman wawancara, sumber data penelitian juga dikumpulkan melalui kajian dokumen yang relevan.

Untuk menguji validitas data, maka data yang terkumpul diverifikasi terlebih dahulu keabsahan data dilakukan melalui konfirmasi hasil observasi, wawancara dengan informan, dan konfirmasi dokumen dengan hasil wawancara. Uji kredibilitas data dilakukan dengan memperpanjang waktu pengamatan, meningkatkan ketekunan, triangulasi data, member chek, dan menggunakan bahan referensi.

Tahap analisis data menggunakan model interaktif Miles \& Huberman (1992) yakni dilakukan secara berlanjut, berulang dan terusmenerus di dalam melaksanakan pengumpulan data, reduksi data, penyajian data dan mengambil kesimpulan

\section{HASIL DAN PEMBAHASAN}

Praktik pendidikan multikultural dalam kehidupan di sekolah Global Inbyra School (GIS) and Pelita Harapan Bangsa (PHB) dilaksanakan secara terpadu melalui kegiatan intrakurikuler dan kegiatan ekstrakurikuler. Kegiatan ini sangat beragam, disesuaikan dengan minat dan bakat peserta didik. Hal tersebut dilakukan agar siswa tidak bosan. Berikut ini adalah salah satu contoh jenis kegiatan ekstrakulikuler di GIS:

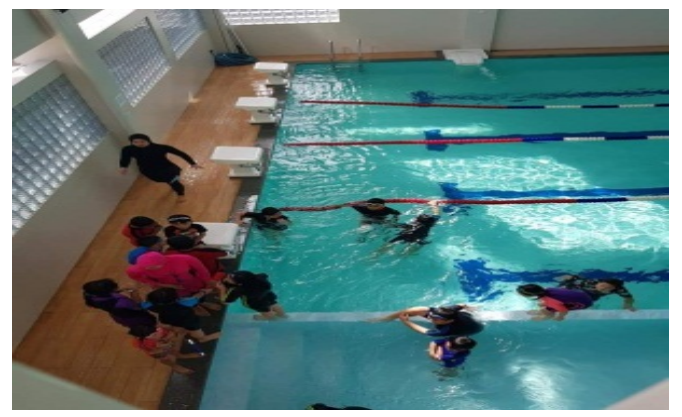

Gambar 1. Ekstrakurikuler renang sekolah GIS

Kegiatan tersebut dilaksanakan tanpa paksaan dari siapapun. Pendidikan multikultural adalah suatu pendekatan progresif untuk melakukan transformasi pendidikan secara menyeluruh membongkar kekurangan, 
kegagalan dan praktek diskriminasi dalam proses pendidikan (Supriati, 2017). Pengembangan nilai-nilai multikultural dalam kegiatan intrakurikuler melalui pembelajaran di kelas memiliki peran yang strategis dalam upaya tercapainya tujuan pendidikan multikultural pada siswa di kedua sekolah tersebut. Pendidikan multikultural tidak diselenggarakan secara sistematis pada mata pelajaran yang berdiri sendiri.

Pendidikan multikultural di Indonesia diajarkan secara terintegrasi dengan beberapa mata pelajaran tertentu (Prastyawati, 2015). Implementasi nilai-nilai multikultural secara substansial sudah tampak dalam kegiatan di dalam kelas, seperti guru mengaitkan materi pelajaran dengan pengembangan nilai-nilai multikultural pada peserta didik; guru dalam memberikan tugas kelompok; serta kegiatan diskusi kelas. Peserta didik pada jenjang sekolah dasar harus dibekali dengan konsep wawasan pengetahuan secara jelas, supaya tidak ada pengaburan pengetahuan di jenjang selanjutnya (Hidayat, 2018). Berikut ini gambar mengenai proses pembelajaran di kelas

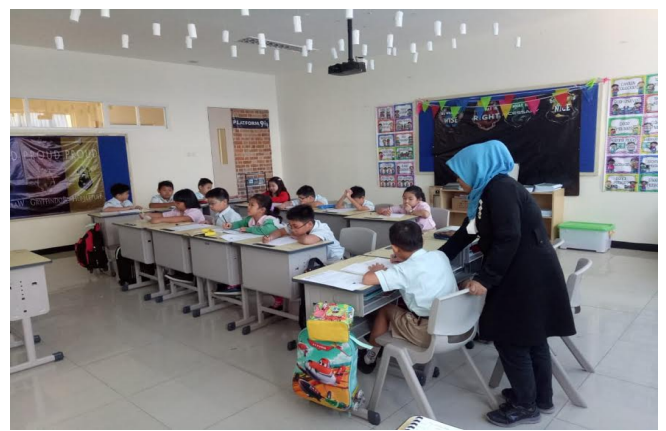

Gambar 2 . Kegiatan Belajar Mengajar di GIS

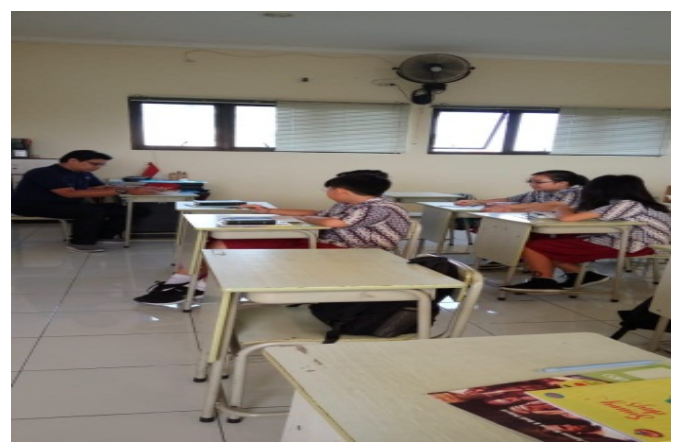

Gambar 3. Proses belajar mengajar di PHB
Pendidikan pada masyarakat pluralitas senantiasa bertumpu pada tiga pilar yaitu orang tua, sekolah, dan masyarakat (Indriyanti, 2016). Pengembangan sikap saling menghormati antar sesama di dalam mengikuti kegiatan pembelajaran memotivasi peserta didik dalam belajar merupakan bagian dari pengembangan nilai-nilai multikultural guna membangun kualitas belajar peserta didik.

Berdasarkan hasil observasi, beberapa nilai multikultural yang ditanamkan pada peserta didik dalam kegiatan intrakurikuler sebagai berikut di SD GIS a) pada jam pertama siswa berbaris di luar kelas kemudian masuk satu persatu dengan tertib; b) pada jam pertama guru kelas masuk sebentar memberikan pendampingan dengan menginformasikan pelajaran apa saja yang akan siswa pelajari sebagaimana yang ada dalam buku agenda, serta memberi arahan-arahan; c) pada jam terakhir, setelah pelajaran usai guru kelas masuk lagi untuk memulangkan siswa; d) kegiatan pembelajaran dilaksanakan oleh guru bidang studi; e) pada jam pertama diawali dengan do'a bersama; f) demikian juga pada jam terakhir.

Di SD PHB: a) pada jam ke 0 setiap pagi diadakan kegiatan morning assembly di lapangan halaman sekolah dari kelas 1 sampai dengan kelas 6 kegiatan diawali dengan memberi salam kepada masing-masing guru yang ada dengan menyebut namanya, dilanjutkan dengan do'a bersama sesuai agama dan keyakinan masing-masing, menyanyikan lagu nasional, menyanyikan lagu mars PHB, memberi ucapan selamat kepada yang sedang ulang tahun; b) kemudian masuk ke kelas masing-masing dengan tertib; c) pada pembelajaran jam pertama diawali dengan do'a bersama sesuai agama dan kepercayaan masing-masing, d) begitu juga pada jam terakhir; e) pada pelaksanaan kegiatan pembelajaran guru mengintegrasikan pada sub tema yang sesuai dengan nilai multikultural, pengaturan piket kelas, penerapan aturan tata tertib kelas dan sangsinya, penanaman nilai multikultural saling menghormati, saling menghargai perbedaan, kebersamaan, dan tenggang rasa.

Kegiatan ekstrakurikuler memiliki peranan yang strategis sebagai upaya pengembangan nilai-nilai multikultural peserta didik dalam pembelajaran di luar kelas, seperti 
Kurotul Aeni dan Tri Astuti

IMPLEMENTASI NILAI-NILAI MULTIKULTURAL DI SEKOLAH DASAR

REFLEKSI EDUKATIKA : Jurnal Ilmiah Kependidikan, Volume 10, Nomor 2, Juni 2020, hlm. 178-186

kegiatan keagamaan, keolahragaan, kemasyarakatan. Beberapa kegiatan ekstrakurikuler di sekolah GIS dan PHB merupakan bagian yang tidak bisa dipisahkan dengan pengembangan nilai-nilai multikultural meskipun secara eksplisit tidak dijelaskan.

Secara implisit tujuan dari kegiatan ekstrakurikuler merupakan bagian dari pengembangan nilai-nilai multikultural peserta didik. Hal tersebut didasarkan pada hasil wawancara dengan kepala sekolah GIS dan PHB. Beliau menyampaikan bahwa "di dalam pelaksanaan kegiatan ekstrakurikuler juga terdapat proses penanaman dan pengembangan nilai multikultural"

Berdasarkan hasil observasi, pelaksanaan pengembangan nilai-nilai multikultural melalui kegiatan ekstrakurikuler yang dilakukan peserta didik di GIS dan PHB, meliputi: a) Sports/Olah raga: Basket Ball, Futsal, Voli, Badminton, Tenis meja, Renang, Wushu; Music Programme/Program Musik: Piano, Keyboard, Drum, Vocal, Biola, Gitar; Clubs and Organisation dan Organisasi: performing arts, young readers club library, young investigators, Chinese Art Club, Computer Club, Young Artists Club, Cooking Club, English Club, Chess Club.

Nilai-nilai multikultural melalui kegiatan ekstrakurikuler ini adalah toleransi; menerima perbedaan; memahami persepsi orang lain; mencegah terjadinya stereotipe; menjalin komunikasi; kerjasama; empati; keselarasan; keadilan; demokratis. Hal tersebut peneliti lihat ketika proses observasi berlangsung. Ketika siswa sedang berkemah misalnya, nilai tersebut nampak diantara para siswa. Mereka selalu bekerjasama dalam menyelesaikan tugas yang diberikan oleh guru. berikut adalah dokumentasi pada saat siswa sedang mengikuti kegiatan pramuka.

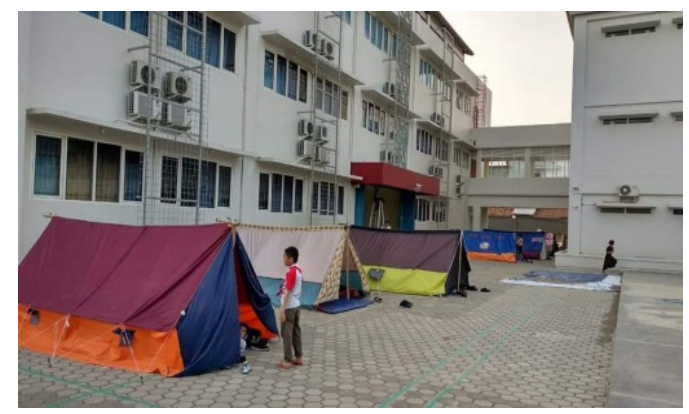

Gambar 4. Kegiatan kemah Pramuka
Pada saat pelaksanaan kegiatan ini, kepala sekolah, guru, dan siswa memiliki pemahaman yang sama dan berpengaruh positif dalam pengembangan nilai-nilai multikultural sebagai upaya membangun karakter peserta didik. Kepala sekolah sebagai pucuk pimpinan di lembaga SD GIS dan SD PHB, mempunyai peranan yang sangat penting dan positif dalam mengimplementasikan nilai-nilai multikultural di sekolah.

Berbagai peran sangat dominan ditunjukkan oleh kepala sekolah GIS dan PHB, yakni sebagai: a) supervisor; b) inisiator; c) teladan; d) motivator; e) pelindung; f) penggerak kegiatan sekolah; g) pembimbing. Berdasarkan hasil wawancara dengan ibu Diah (Kepala Sekolah PHB), Beliau menyampaikan bahwa "saya selalu memberikan dukungan nyata pada guru dan siswa atas kegiatan yang mereka lakukan di sekolah dalam rangka penanaman nilai karakter".

Peran supervisor bahwa kepala sekolah mempunyai kewajiban untuk selalu memberikan pengawasan pada semua warga sekolah agar selalu mengimplementasikan nilai multikultural sesuai dengan sosio kultural bangsa yang bersumber dari falsafah Pancasila; Kepala sekolah memberi teladan pada semua warga sekolah di kedua sekolah misalnya datang ke sekolah tepat waktu, menjaga kebersihan lingkungan sekolah, kerjasama dalam melaksanakan kegiatan.

Kepala sekolah sebagai inisiator, penggagas ide bersama dengan wakil kepala sekolah, dewan guru, juga komite sekolah; Kepala sekolah sebagai motivator, bahwa kepala sekolah sebagai pucuk pimpinan merasa berkewajiban memberikan dorongan pada semua sivitas akademika agar membiasakan diri mengimplementasikan nilai-nilai multikultural yang dilandasi falsafah Pancasila.

Peran Kepala sekolah sebagai pelindung yakni melindungi sivitas akademika dalam mewujudkan program-program sekolah supaya terarah, mengayomi sivitas akademika tanpa membeda-bedakannya. Pelaksanannya seperti pada saat ada warga yang kena musibah tanpa membeda-bedakan mereka mengunjunginya, saat warga sakit, warga meninggal dunia, punya hajat lainnya. Kepala sekolah sebagai penggerak kegiatan sekolah, yakni menunjukkan keikutsertaannya dalam setiap 
kegiatan bersama-sama dengan sivitas akademika yang lain. Hal tersebut menunjukkan adanya kebersamaan dalam perbedaan.

Kepala sekolah sebagai pengarah ditunjukkan dengan peran memberi arahan secara adil dan setara tanpa memandang agama, bangsa, ras, etnis. Multikultural adalah kenyataan yang harus diterima oleh manusia, kenyataan tersebut tidak harus membuat manusia yang berasal dari luar kultur yang berbeda menjadikan perpecaham (Nanda, 2019).

Guru mempunyai pengaruh positif dalam proses transformasi baik ilmu pengetahuan, sikap maupun perilaku siswanya dalam upaya mengembangkan nilai-nilai multikultural. Peran guru di GIS dan PHB ditunjukkan sebagai: a) supervisor; b) advisor yakni memberi nasehat, mengarahkan pada siswa ke hal-hal yang lebih baik yang seharusnya dilakukan; c) pembimbing; d) contoh teladan dalam mempraktikkan nilainilai multikultural; e) psikolog bagi siswa yang bermasalah; f) fasilitator; g) komunikator lintas budaya.

Siswa sebagai subjek didik sekaligus pelaku aktivitas atau kegiatan di sekolah berperan positif terhadap proses implementasi nilai-nilai multikultural di GIS dan PHB. Siswa adalah insan manusia yang memiliki rasa ingin tahu yang tinggi dan sebagai pribadi yang sangat unik (Warpala, 2019). Melalui kegiatan intrakurikuler maupun ekstrakurikuler siswa selaku subjek didik mendapatkan bahan atau materi pelajaran, mendapat nasehat dari guru, melaksanakan tata tertib sekolah dengan penuh tanggung jawab, disiplin dalam menerima tugas dari guru, serta berperilaku baik.

Hasil penelitian yang dilaksanakan memiliki persamaan dengan riset Fakhriyah, (2014), penelitian Mutohhar, Pubasari, dan Fajrie (2015), penelitian Ismaya dan Romadlon (2017), riset Rachman et al (2017), penelitian Perdana (2018), riset Kusumadewi (2019), serta penelitian Pratiwi dan Kuryanto (2019). Persamaan yang dimaksud yaitu adanya penekanan pada karakter peserta didik yang dibentuk. Adapun perbedaannya pada fokus penelitian yang dilakukan.

\section{Persamaan dan Perbedaan Implementasi Nilai-nilai Multikultural di SD GIS dan SD PHB}

Persamaan dalam implementasi Nilainilai multikultural di SD GIS dan SD PHB yakni: 1) kurikulum pendidikan multikultural secara spesifik belum ada namun sekolah sudah menerapkan dan mengembangkan nilai-nilai multikultural pada kurikulum yang dianut di sekolah masing-masing; 2) keberagaman dalam kehidupan beragama dengan memberikan kesempatan pada sivitas akademika untuk melaksanakan ibadah sesuai dengan agama dan kepercayaan masing-masing, sekolah menyediakan guru agama juga ruang untuk ibadah sesuai agama masing-masing. 3) nilainilai multikultural sudah diimplementasikan dalam kehidupan di lingkungan sekolah seharihari; kegiatan pembelajaran baik intrakurikuler maupun ekstrakurikuler; komunikasi antar sivitas akademika; juga dalam berbagai program sekolah.

Nilai-nilai tersebut seperti, nilai saling menghargai dan menghormati atau toleransi; tidak membeda-bedakan atau diskriminasi; tenggang rasa; empati; tolong menolong; kesetaraan; keadilan; komunikasi; kekompakan. Nilai-nilai multikultural yang telah dimiliki tersebut diyakini kebenarannya dan dilakukan oleh sivitas akademika tersebut didorong oleh prinsip dan tujuan yang dikembangkan oleh sekolah sesuai visi misinya.

Perbedaan dalam implementasi nilainilai multikultural di sekolah GIS: 1) penerapan bahasa Inggris sebagai bahasa pengantar dalam kehidupan di sekolah, membuat siswa tidak asing dengan istilah bahasa Inggris kaitannya dengan penggunaan teknologi; percaya diri dalam berinteraksi dengan orang asing/WNA membuat siswa asli membantu siswa dari bangsa asing untuk beradaptasi dan berbaur dalam kegiatan seharihari sehingga mereka dapat belajar bersama dengan nyaman; 2) implementasi nilai-nilai multikultural dalam scope yang lebih besar /antar bangsa di sekolah GIS yakni melalui mata pelajaran character building; 3) adanya program kurikulum ganda, yakni perpaduan dan pengintegrasian kurikulum nasional dan internasional (cambridge) yang berangsurangsur menyeimbangkan potensi peserta didik, peluang, latar belakang etnis, keyakinan agama 
dan cita-cita guna menciptakan individu untuk bersosialisasi dengan budaya yang berbeda. Hal ini menunjukkan bahwa sekalipun pendidikan multikultural tidak diajarkan secara monolitik, namun nilai-nilai multikultural sudah ada di dalam program kurikulum ganda tersebut.

Perbedaan dalam implementasi nilainilai multikultural di sekolah PHB: 1) kegiatan Morning Assembly yang dilaksanakan setiap pagi menyatukan suasana yang membangkitkan semangat di pagi hari guna memecahkan kejenuhan sebelum kegiatan pembelajaran dimulai. 2) Kurikulum Pendidikan multikultural tercantum dalam aspek kurikulum nasional, yakni terintegrasi dengan pendidikan budaya karakter bangsa; 3) Implementasi nilai multikultural dalam kegiatan di sekolah mencerminkan kehidupan yang mendasarkan pada keberagaman yang didorong oleh cita-cita sekolah untuk terciptanya keselarasan, keserasian dan keseimbangan antar sivitas akademika yang berbeda.

Banks (2005:3) menjelaskan bahwa pendidikan multikultural dipahami sebagai konsep pendidikan yang memberikan kesempatan sama kepada semua peserta didik tanpa memandang gender, kelas sosial, kelompok etnik, ras, karakteristik kultural mereka, untuk mendapatkan kesempatan sama di sekolah. Hal tersebut dibuktikan juga oleh sekolah PHB, sekalipun tidak ada kurikulum pendidikan multikultural namun pemahaman tentang keberagaman dan implementasinya dalam kehidupan di sekolah sudah tampak.

Reformasi Kurikulum ditunjukkan oleh dua lokasi penelitian bahwa pendidikan multikultural tidak diberikan dalam mata pelajaran yang berdiri sendiri. Isi substansi dari pendidikan multikultural ditunjukkan dalam berbagai program kegiatan sekolah. Pandangan dari beberapa guru menyatakan bahwa pendidikan multikultural terintegrasi dengan semua mata pelajaran dan mengacu pada kurikulum nasional. Di sekolah GIS, substansi pendidikan multikultural mengacu pada kurikulum nasional dan kurikulum internasional (Cambridge).

Sedangkan di sekolah PHB mengacu pada kurikulum nasional. Jadi pada kedua sekolah tersebut tidak menyelenggarakan pendidikan multikultural secara khusus, sehingga kurikulum berkaitan pendidikan multikultural tidak ada. Namun kedua sekolah tersebut menunjukkan pengembangan nilainilai multikultural terkait dengan keberagaman, yakni: 1) upaya mengembangkan Rasa Keadilan ditunjukkan oleh sekolah GIS yakni tidak membeda-bedakan di dalam pelayanan pendidikan dan sarana prasarana pada sivitas akademika. Siswa laki-laki dan perempuan memiliki kesempatan yang sama dalam mengikuti kegiatan di sekolah baik intrakurikuler maupun ekstrakurikuler. Di sekolah PHB dalam pemanfaatan sarana dan prasarana ditunjukkan bahwa semua siswa memperoleh kesempatan yang setara baik pada kegiatan intrakurikuler maupun ekstrakurikuler.sekolah tidak membatasi kelompok tertentu untuk menjadi siswa di sekolah ini.sekolah lebih mengembangkan rasa keadilan kepada siswa melalui berbagai kegiatan seperti bakti sosial baik secara internal maupun eksternal (di masyarakat); 2) Kemampuan Budaya ditunjukkan oleh sekolah GIS dan PHB yakni adanya kesadaran akan keberagaman yang didorong oleh visi misi sekolah masing-masing. Keberagaman dalam kehidupan di sekolah tersebut membantu siswa mempunyai kemampuan berbudaya. 3) Kesetaraan Pendidikan ditunjukkan oleh sekolah GIS dan PHB dengan memberi kesempatan pada masyarakat yang ingin mendaftar menjadi siswa di sekolah tersebut.

Tidak membeda-bedakan agama, suku, bangsa, status sosial ekonomi keluarga. Semua siswa diberikan pelayanan yang sama sesuai kebutuhan masing-masing. Zamroni (2011: 140), menyatakan bahwa pendidikan multikultural merupakan suatu bentuk reformasi pendidikan yang bertujuan untuk memberikan kesempatan yang setara kepada siswa tanpa memandang latar belakangnya, sehingga semua siswa dapat meningkatkan kemampuan yang setara optimal sesuai dengan ketertarikan, minat dan bakat yang dimiliki.

\section{SIMPULAN}

Implementasi nilai-nilai multikultural di GIS Tegal ditemukan nilai yang relevan dengan kehidupan masyarakat multikultural terdapat dalam kurikulum Character building antara lain saling menghargai; saling menghormati; tidak membeda-bedakan; tidak menghina; tenggang rasa; empati; kerjasama. Implementasi nilai-nilai multikultural di PHB 


\section{Kurotul Aeni dan Tri Astuti \\ IMPLEMENTASI NILAI-NILAI MULTIKULTURAL DI SEKOLAH DASAR \\ REFLEKSI EDUKATIKA : Jurnal Ilmiah Kependidikan, Volume 10, Nomor 2, Juni 2020, hlm. 178-186}

ditemukan nilai yang relevan dengan kehidupan masyarakat multikultural terdapat dalam kurikulum umum Pendidikan dan Kebudayaan, yakni pengintegrasian pendidikan budaya dan karakter bangsa. Nilai-nilai tersebut meliputi: empati; tenggang rasa; hidup rukun; tidak pilih-pilih teman, membantu teman yang kesulitan; menghargai dan menghormati teman lain yang berbeda agama.

Keberagaman akan latar belakang budaya, agama, suku, bangsa, bahasa, tingkat sosial ekonomi keluarga disadari oleh sivitas akademika, sehingga mereka dapat mengimplementasikannya di manapun mereka berada. Upaya memfasilitasi keberagaman tersebut, kedua sekolah mewujudkannya dengan tidak membeda-bedakan/diskriminatif. Pelaksanaan kegiatan intrakurikuler dan ekstrakurikuler diselenggarakan dengan adil. Kegiatan pembelajaran tidak membedabedakan setiap siswa dari latar belakang apapun.

\section{DAFTAR PUSTAKA}

Baldah, Wardatul. Sumarna, Cecep dan Yuniarto, Bambang. 2016. Pengaruh Penanaman Nilai-nilai multikultural Terhadap Pembentukan Sikap Pluralis Siswa di MTS Negeri Babakan Ciwaringin Kabupaten Cirebon. Jurnal Edueksotis, 1 (1).

Desmita. 2016. Pikologi Perkembangan Peerta Didik. Bandung: Remaja Rosda Karya.

Fakhriyah, Fina., Roysa, Mila., dan Sumaji. 2014. Penerapan Pembelajaran Tematik Berwawasan Multiple Intellegence Dalam Upaya Membentuk Karakter Siswa Di SD IT Al Islam Kudus. Refleksi Edukatika : Jurnal Ilmiah Kependidikan, 4 (1).

Hanum, Farida dan Rahmadonna, Sisca. 2010. Implementasi Model Pembelajaran Multikultural SD di DIY. Jurnal Penelitian Ilmu Pendidikan, 3 (1): 89102.

Hidayat, Muhamad Taufik dan Retnasari, Lisa. 2018. Pendidikan Multikultural dengan Pendekatan Aditif di Sekolah Dasar.
Jurnal Pendidikan dan Ilmu Sosial, 28 (1).

Indriyanti, Poppy dan Wijayanti, Dwi. 2016. Pendidikan Multikultural berbasis Seni Budaya di SD Taman Muda Ibu Pawiyatan Yogyakarta. Jurnal Sosiohumaniora, 3 (1).

Ismaya, Erik Aditia. 2011. Pendidikan Multikultural di Yogyakarta. (Tesis). Yogyakarta: Universitas Gadjah Mada.

Ismaya, Erik Aditia dan Romadlon, Farid Noor. 2017. Strategi Membentuk Karakter Semangat Kebangsaan Anggota Ambalan Kyai Mojo dan Nyi Ageng Serang. Refleksi Edukatika : Jurnal Ilmiah Kependidikan, 7 (2): 140144.

Kusumadewi, Subekti. 2019. Pengembangan Model Manajemen Kurikulum Berbasis Penguatan Pendidikan Karakter Untuk Meningkatkan Mutu Pembelajaran Di Sekolah Dasar. Refleksi Edukatika : Jurnal Ilmiah Kependidikan, 10 (1): 8796.

Lincoln, Y Vonna S.\& Guba, Egon G. 1985. Naturalistic Inquiry. London: Sage Publications. Inc.

Lincoln, P. Z. 2011. Educational Equality or Educational Equity. NUCB Journal of Economics And Information Science, 60 (1).

Miles, M.B. and Hubermen, A.M. 1992. Analisis Data Kualitatif (Terjemahan Tjetjep Rohindi Rohadi). Jakarta: Universitas Indonesia Press.

Mutohhar., Pubasari, Imaniar, dan Fajrie, Nur. 2015. Revitalisasi Budaya Lokal Kota Kudus Dalam Pengembangan Bahan Ajar Di Sekolah Dasar. Refleksi Edukatika : Jurnal Ilmiah Kependidikan, 5 (1).

Najmina, Nana. 2018. Pendidikan Multikultural dalam Membentuk Karakter Bangsa Indonesia. Jurnal 
Pendidikan Ilmu-Ilmu Sosial 10 (1): 5256.

Nanda, Maulidan. 2019. Strategi Guuru Pendidikan Agama Islam dalam Menanamkan Nilai-nilai Pendidikan Multikultural di SMA Negeri 07 Kota Medan. Jurnal Observasi. Vol. 02. No 02.

Peraturan Menteri Pendidikan dan Kebudayaan. 2016. Standar Kompetensi Lulusan Pendidikan Dasar dan Menengah. Jakarta: Kemendikbud.

Perdana, Novrian Satria. 2018. Implementasi Peranan Ekosistem Pendidikan Dalam Penguatan Pendidikan Karakter Peserta Didik. Refleksi Edukatika : Jurnal Ilmiah Kependidikan, 8 (2): 182-191.

Prastyawati, lia dan Hanum, Farida. 2015. Pengembangan Model Pembelajaran Pendidikan Multikultural berbasis Proyek di SMA. Jurnal Harmoni Sosial, 2 (1).

Pratiwi, Ika Ari dan Kuryanto, Mohammad Syaffruddin. 2019. Correlation Betengan Traditional Games On Locomotor Movements And Characters. Refleksi Edukatika : Jurnal Ilmiah Kependidikan, 10 (1): 71-76.

Rachman, et al .2017. Pengembangan Model Manajemen Pelatihan dan Pengembangan Pendidikan Karakter Berlokus Padepokan Karakter. Refleksi Edukatika : Jurnal Ilmiah Kependidikan, 8 (1): 16-26.
Sudrajat. 2014. Pendidikan Multikultural Untuk Meningkatkan Kualitas Pembelajaran IPS di SD. JIPSINDO, 1 (1): 1-19.

Sugiyono. 2011. Metode Penelitian Pendidikan: Pendekatan Kuantitatif, Kualitatif, dan $R \& D$. Bandung: Alfabeta.

Supriati, Atin dan Nasutioan, Aida Rahmi. 2017. Implementasi Pendidikan Multikultural Dalam Praktik Pendidikan di Indonesia. Elementary, 3.

Tilaar, H.A.R. dan Nugroho, R.. 2009. Kebijakan Pendidikan: Pengantar untuk Memahami Kebijakan \& Kebijakan Pendidikan sebagai Kebijakan Publik. Yogyakarta: Pustaka Pelajar.

Undang-undang Republik Indonesia Nomor 20 Tahun 2003 tentang Sistem Pendidikan Nasional.

Wahyudin, Apri dan Elhefni. 2017. Strategi Pengembangan Pendidikan Multikultural di Indonesia. Jurnal Elementary, 3.

Warpala, I Wayan Sukra. 2019. Pembelajaran Kontekstual: Sebuah Inovasi Penerapan Pendidikan Multikultural dan Belajar untuk Penemuan. Media Edukasi, 3 (1).

Wulandari, Taat. 2013. Pendidikan Multikultural di SMP Maria Immaculata Dan SMP Negeri 5 Yogyakarta, (Disertasi). Yogyakarta: Program Pascasarjana, UNY.

Zamroni. 2011. Pendidikan Demokrasi pada Masyarakat Multikultural. Yogyakarta: Surya Sarana Grafika. 